\title{
The harbour porpoise (Phocoena phocoena) in the central German Bight: phenology, abundance and distribution in 2002-2004
}

\author{
Frank Thomsen $\cdot$ Martin Laczny $\cdot$ Werner Piper
}

Received: 29 January 2007 / Revised: 12 July 2007 / Accepted: 12 July 2007 / Published online: 3 August 2007

(C) Springer-Verlag and AWI 2007

\begin{abstract}
The harbour porpoise (Phocoena phocoena) is widely distributed in the North Sea. During both the SCANS 1994 and 2005 surveys, porpoises were commonly encountered in offshore waters, for example in the central German Bight. However, information on year-round abundance and distribution of harbour porpoises in that area on a monthly basis was lacking. Between 2002 and 2004, we undertook 26 aerial line-transect surveys in a $2,600 \mathrm{~km}^{2}$ area in the central German Bight, $100 \mathrm{~km}$ north of the Island of Borkum (Eastern Frisia). Data were analysed with DISTANCE software. A total of 406 porpoises were sighted. Sighting rates (=sightings $/ \mathrm{km}$ transect) peaked in July 2002, February, May and September 2003, and in January and April 2004. Absolute densities $(g(0)$ corrected) ranged between 0.14 and 1.54 animals $/ \mathrm{km}^{2}$ (peak in April 2004). Proportion of calves varied between 3.4 and $27.3 \%$. Our results show a highly irregular appearance of harbour porpoises in the study area with no apparent seasonal trends in occurrence but peaks in single months. We propose that the area is used as a transit route with harbour porpoise moving in from regions of high density in summer (Northern Frisia) and early spring (Eastern Frisia).
\end{abstract}

Keywords Harbour porpoise $\cdot$ Central German Bight

Communicated by H.-D. Franke.

F. Thomsen $\cdot$ M. Laczny $\cdot$ W. Piper

Biologisch-landschaftsökologische-Arbeitsgemeinschaft (biola),

Gotenstraße 4, 20097 Hamburg, Germany

F. Thomsen $(\square)$

Centre for Environment,

Fisheries and Aquaculture Science (Cefas),

Burnham Laboratory, Remembrance Avenue,

Burnham-on-Crouch, Essex CMO 8HA, UK

e-mail: frank.thomsen@cefas.co.uk

\section{Introduction}

Effective conservation requires information on seasonal distribution and inter-annual trends of occurrence of the species in question. In the past, such information was missing for most cetacean species. In recent years, with the improvement of field techniques, and due to a higher effort of at-sea surveys, data have been collected that aid in the conservation of various cetacean populations in many regions (overview in Perrin et al. 2002). One region where cetacean conservation has recently received particular attention has been the German Bight. The German Bight is the southeastern part of the North Sea that abuts corners the Netherlands and Germany to the south as well as Denmark and Germany to the east. To the north it is limited by $56^{\circ} \mathrm{N}$ and to the west it is limited by $4^{\circ} \mathrm{E}$ in the vicinity of the Dogger Bank (Fig. 1). It is used very frequently by the most common cetacean species in northwestern European waters, the harbour porpoise (Phocoena phocoena). The German Bight is also a prospected area for large-scale offshore wind farm development with presumably negative effects on harbour porpoises (reviews by Madsen et al. 2006; Thomsen et al. 2006a). These and other anthropogenic influences have called for extensive studies on the occurrence and distribution of harbour porpoises in that region.

Results obtained so far indicate a relatively high variability in porpoise occurrence in the German Bight. In the summer of 1994, Hammond et al. (2002) found high densities in the eastern part, along the coast of Northern Frisia and Denmark, but decreasing densities in the centre of the Bight and in the southern areas off Eastern Frisia (coast of Netherlands and Lower-Saxony, Germany). Later investigations, using data from aerial surveys (1995/1996; 2002 2005), incidental sightings and strandings, confirmed the high summer-densities of porpoises off Northern Frisia 


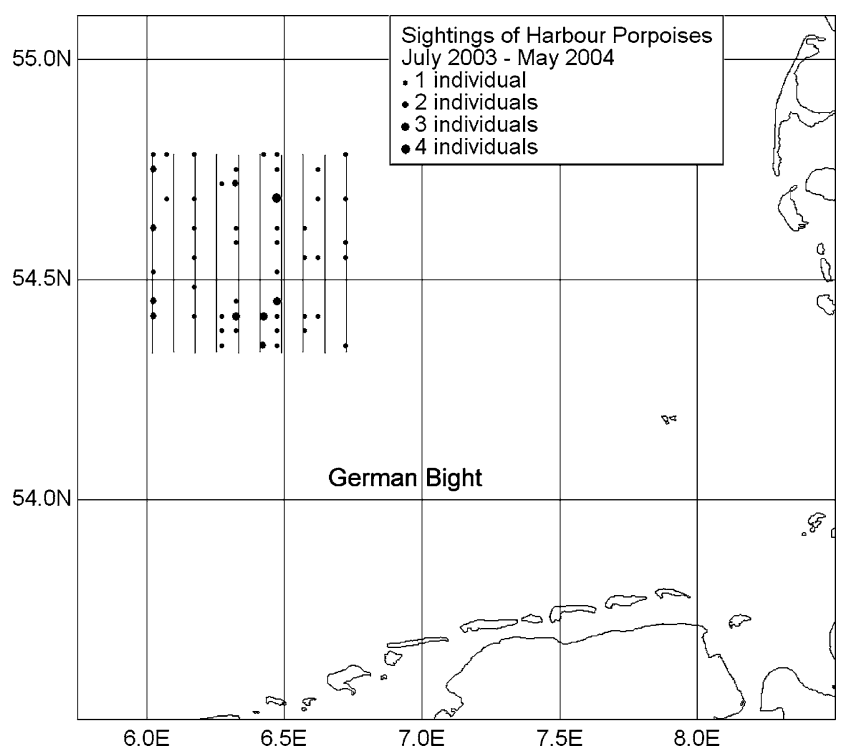

Fig. 1 The transect layout and the distribution of sightings of harbour porpoises during the porpoise-only surveys between July 2003 and May $2004(n=69)$

(Sonntag et al. 1999; Scheidat et al. 2004a, b, 2006; Siebert et al. 2006). However, densities in the southern part of the German Bight and surrounding waters were higher than expected based on previous findings, especially between February and May (Camphuysen 1994, 2004; Witte et al. 1998; Haelters et al. 2004; Scheidat et al. 2006; Thomsen et al. 2006b; for a preview of SCANS II results see Hammond 2006). These studies indicate two peaks in harbour porpoise occurrence in different parts of the German Bight at different times of the year: one in late winter and early spring off Eastern Frisia, the other during spring and summer off Northern Frisia. If porpoises travel from one region to the other, it should be expected that the central areas of the German Bight would be used as a transit route with high occurrence during probable times of migrations (spring, fall). Therefore, studies on the occurrence of harbour porpoises in the central German Bight are of special interest. Hammond et al. (2002) estimated porpoise densities in an area comprising the central German Bight (SCANS-surveyblock $\mathrm{G}$ ) to be 0.34 porpoises per $\mathrm{km}^{2}$. In 2005 , densities in the corresponding block (U) were estimated to be 0.23 porpoises per $\mathrm{km}^{2}$. However, the survey blocks were quite large and effort restricted to four weeks in the summer of 1994 and 2005 (Hammond et al. 2002; Hammond 2006). For May-August 2002 and 2003, Scheidat et al. (2004b) estimated a density of 0.59 and $0.72 / \mathrm{km}^{2}$ respectively for the offshore areas of the German Exclusive Economic Zone. Their results also indicate seasonality with higher numbers of porpoises and a more clustered occurrence in spring and summer compared to fall and winter. However, due to the large-scale of the survey, the effort was restricted in most cases to one survey per season and year in each survey block. No study has looked at harbour porpoises in the central German Bight on at least a monthly basis. Therefore, knowledge on the movements of porpoises in that area is lacking.

In this paper we present findings from a systematic study in a 2,600 $\mathrm{km}^{2}$ offshore area in the central German Bight, $100 \mathrm{~km}$ north of the coast of Eastern Frisia. We collected data using line transect aerial surveys between 2002 and 2004. We will present data on relative and absolute densities of harbour porpoises. Based on our results, the significance of the central German Bight for harbour porpoises and the status of the species therein will be discussed.

\section{Methods}

\section{Data collection}

We collected data between July 2002 and July 2004 in a study area located in the central German Bight, about $100 \mathrm{~km}$ north of the island of Borkum, Eastern Frisia $\left(54^{\circ} 20.000^{\prime}-54^{\circ} 47.100^{\prime} \mathrm{N} ; 006^{\circ} 01.200^{\prime}-006^{\circ} 43.500^{\prime} \mathrm{E}\right.$; Fig. 1). The water depth varied from $30 \mathrm{~m}$ to $>40 \mathrm{~m}$. We used line transect methodology following the distance sampling approach after Buckland et al. (2001) (see also Thomsen et al. 2004 for a detailed methodology in German, and Thomsen et al. 2006b for further details). From July 2002 until June 2003, the survey area comprised $1,600 \mathrm{~km}^{2}$ with 8 transect lines of $57.6 \mathrm{~km}$ length each, a spacing between the lines of $3.7 \mathrm{~km}$, and a total transect length of $460 \mathrm{~km}$. From the end of July 2003 until July 2004 app. 2,600 km² were surveyed with 10 transects of $50 \mathrm{~km}$ each, a line spacing of $5 \mathrm{~km}$, and a total transect length of $500 \mathrm{~km}$ (Fig. 1). As survey airplane, we used a high-winged, twin-engine BN2-Islander, equipped with bubble windows on the rear seats. We only collected data in good or moderate survey conditions (seastate $<3 \mathrm{bft}$, visibility $>5 \mathrm{~km}$ ). Data was collected during specialized porpoise trips at an altitude of 500 and $600 \mathrm{ft}(152 / 183 \mathrm{~m})$ as well as during combined porpoise/seabird surveys at an altitude of $250 \mathrm{ft}(76 \mathrm{~m})$. We started with three porpoise-only flights in July 2002, August 2002 and in February 2003; from May 2003 until July 2004 , both methods were used for at least one survey per month (see Table 2).

Three observers were used during the surveys: two principal observers were placed at the rear bubble windows (search angle $=0^{\circ}-<60^{\circ}$ ). One control observer was placed at a flat window behind the pilot (search angle $=20^{\circ}-<60^{\circ}$ ). The principal observers switched places during a break at half time, the control observer switched places on each transect, depending on sighting conditions. Observers were acoustically isolated from each other through earplugs and headphones. From 
the onset of the survey, the observers searched continuously for porpoises. At each sighting, the exact time was noted (UTC, synchronised with an on-board GPS, model LX-202000 Flight Recorder, Filser Electronics) and recorded aurally on dictaphone. The sighting angle was measured with a clinometer (Suunto PM 5/360 PC) and also noted. Additionally, data on group size, travel direction and the behaviour of the animals were recorded. The flight-track was logged and stored continuously in $3 \mathrm{~s}$ intervals on a Notebook, which was connected to the on-board GPS and displayed using the Fugawi 3.0 software-program. Thus, it was possible to correct deviations from the track line immediately.

\section{Data analysis}

\section{Calculation of sighting rates}

Based on the field notes of the observers, the transects were assigned as valid one sided, valid both sided or invalid. Only valid transects were analysed. Since control and principal observers had different search angles (see above), only the sightings of the latter ones were used in the quantitative analysis. Porpoise-only flights (altitude: $152 \mathrm{~m} / 183 \mathrm{~m}$ ) and combined porpoise/seabird ones ( $76 \mathrm{~m}$ ) were analysed separately. We first calculated the sighting rate, which was defined as the number of porpoises per $\mathrm{km}$ for each transect of each flight. We then calculated the mean sighting rate for each flight. Sighting rates across flights were compared with a KruskalWallis $H$-test. If means differed, we performed a multiple all-pairwise comparison following Dunn's method (Zar 1984).

\section{Calculation of absolute densities}

Absolute densities were calculated with the DISTANCE 4.1, release 2, software-program (Thomas et al. 2003). Distances $x$ to the observation were calculated as $x=v \times \tan \left(90^{\circ}-\varphi\right)$ with $v$ being the altitude in $\mathrm{m}$ and $\varphi$ the angle of declination measured with the clinometer (Buckland et al. 2001). We then calculated the effective strip half-width (esw) cumulatively for all porpoise-only and combined seabird/porpoise flights separately. Here, we used a hazard-rate key function with a simple polynominal series expansion. The esw for the porpoise-only flights was $163 \mathrm{~m}$ (Fig. 2) and $112 \mathrm{~m}$ for the combined porpoise/seabird surveys. Densities were calculated for each flight as $D=n \times G / 2 \mu \times L$ ( $n=$ number of sightings, $G=$ the average group size, $L=$ total transectlength, $\mu=$ effective strip half-width; Buckland et al. 2001; details in Thomsen et al. 2006b).

\section{Distribution of sightings}

The observer noted the sighting time (UTC) using a digital stopwatch that was synchronized with the on-board GPS.

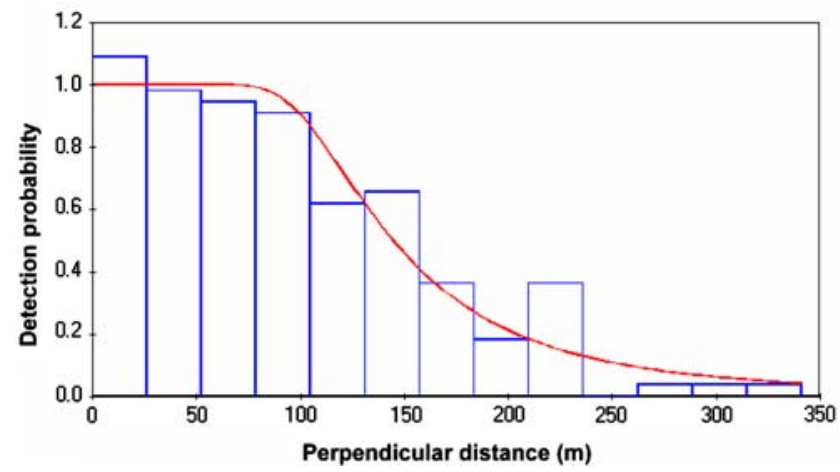

Fig. 2 Detection probability function for harbour porpoises during the porpoise-only aerial surveys (altitude $=183 \mathrm{~m}$; model $=$ hazard rate key function with simple polynominal series expansion; $n=171$ sightings)

The sighting positions were determined from the GPS-track and were plotted into maps using the software-program ArcGIS (8.0). For the second year of observations (July 2003-July 2004), the study area was divided into $10 \mathrm{~km}$ circular zones around the centre of the study area, with almost even coverage across the $0-10 \mathrm{~km}$, the $>10 \mathrm{~km}-$ $<20 \mathrm{~km}$ and the $>20-30 \mathrm{~km}$-zone. The number of sightings in each-zone was compared using a $H$-test (Kruskal-Wallis) or $F$-test in case of normal distribution.

\section{$g(0)$ correction}

In cetacean surveys, the probability to detect an object on the track line is $<1.0$, because observers sometimes miss animals that are present (=perception bias) and diving individuals are unavailable for detection (=detection bias). The corrected density therefore is $D=D \mathrm{x} \times 1 / g(0)$ (after Borchers 2003). We calculated $g(0)$ by using a mark-recapture method combined with published diving data for harbour porpoises after a method first used by Grünkorn et al. (2005). We estimated the perception bias as $p(m)=n 12 / n 1$, where $p(m)$ is the probability of detection by the principal observer, $n 12$ the number of duplicates between main- and control observer (search angle $=20-45^{\circ}$ ), and $n 1$ the number of individuals seen by the control observer. For the availability bias, we first multiplied the number of sightings on each flight with the individual surface time, i.e. the percentage of time porpoises are present in the $0-1 \mathrm{~m}$ water column (Teilmann 2000) to get an estimate on the average surface time. The average surface time for the porpoise only flights was 0.43 with the sighting probability being 0.49 (Table 1 ). This resulted in a $g(0)$ of $0.43 \times 0.49=0.21$. For the combined seabird/porpoise flights, surface time was 0.48 and the sighting probability was 0.43 , resulting in a $g(0)$ of 0.21 . 
Table 1 Estimation of $g(0)$ for the porpoise-only flights (altitude = $152 / 183 \mathrm{~m}$ )

\begin{tabular}{llllrl}
\hline Date & $\begin{array}{l}\text { Number } \\
\text { of sightings }\end{array}$ & $\begin{array}{l}\text { Individual } \\
\text { surface time }\end{array}$ & $\begin{array}{l}\text { Total } \\
\text { surface time }\end{array}$ & N1 & N1\&2 \\
\hline $07 / 28 / 02$ & 24 & 0.41 & 9.84 & 8 & 2 \\
$02 / 14 / 03$ & 32 & $0.44^{\mathrm{b}}$ & 14.08 & 7 & 5 \\
$05 / 26 / 03$ & 23 & 0.45 & 10.35 & 17 & 9 \\
$06 / 22 / 03$ & 13 & 0.39 & 5.07 & 2 & 1 \\
$07 / 28 / 03$ & 10 & 0.41 & 4.10 & 7 & 2 \\
$09 / 13 / 03$ & 18 & 0.39 & 7.02 & 9 & 5 \\
$03 / 06 / 04$ & 15 & 0.55 & 8.25 & 3 & 2 \\
Sum & 135 & & 58.71 & 53 & 26 \\
\hline
\end{tabular}

$\mathrm{N} 1 \& 2$ = duplicate sightings of control and principal observer between $20^{\circ}$ and $45^{\circ}, \mathrm{N} 1=$ sightings of control observer only

Availability bias/average surface time $=0.43$

Perception bias/sighting probability $=0.49$

${ }^{\text {a }}$ Sightings of principal observer in valid transect sections

b Average after Teilmann (2000)

\section{Results}

A total of 346 sightings with 406 individuals (mean group size $=1.17)$ were obtained $($ Table 2$)$. Porpoises were most often encountered alone (86.4\%). Pairs and groups of three or four animals were rare $(10.7,2.3$ and $0.6 \%$, respectively). A total of 17 calves were observed, with average proportion of calves between 3.4\% in May 2003 and 27.3\% in July 2004 (July 2002: 8.6\%, June 2003: 16.6\%, September 2003: 10.71\%, June 2004: 7.1\%).

Porpoises occurred highly irregular in the study area with no apparent seasonal trends, but peaks in single months (e.g. February, April, July, January) (Table 2, Fig. 3). During the porpoise-only flights, most sightings per $\mathrm{km}$ were obtained in February 2003, followed by July 2002, May 2003, January 2004 and September 2003. The remaining 6 months showed rather low sighting rates (Fig. 3). However, the differences in sighting rates across months were not significant $(H$-test, $d f=10, H=17.70, P=0.06)$. During the combined porpoise/seabird flights, most porpoises were seen in April 2004, followed by May 2003, June 2004 and February 2004. There were significant differences in sighting-rates across months with those in April 2004 being significantly higher than those in December $2003(H$-test, $d f=11$, $H=28.83, P=0.002$; Dunn's method $P<0.05$ ).

Absolute estimates of abundance ranged between 0.14 and 1.54 porpoises per $\mathrm{km}^{2}$ with the temporal occurrence as described above and the maximum being in April 2004 (Table 3). Only four surveys resulted in densities $>1.0 / \mathrm{km}^{2}$ (February and May 2003, April 2004). 11 out of 26 surveys resulted in densities $>0.5$ and $<1.0 / \mathrm{km}^{2}$. The estimates for the remaining 11 surveys were $<0.5 / \mathrm{km}^{2}$. The mean
Table 2 Harbour porpoise sightings in 2002-2004

\begin{tabular}{|c|c|c|c|c|c|}
\hline Date & Altitude (m) & $\mathrm{Km}$ on effort & $\mathrm{S}$ & I & Calves \\
\hline 07/28/02 & 152 & 467 & 24 & 35 & 3 \\
\hline 08/16/02 & 152 & 288 & 4 & 5 & 1 \\
\hline $02 / 14 / 03$ & 183 & 443 & 32 & 36 & \\
\hline $05 / 16 / 03$ & 76 & 396 & 18 & 18 & \\
\hline $05 / 26 / 03$ & 183 & 402 & 23 & 29 & 1 \\
\hline $06 / 14 / 03$ & 183 & 393 & 6 & 6 & \\
\hline $06 / 16 / 03$ & 76 & 427 & 6 & 9 & 4 \\
\hline $06 / 22 / 03$ & 183 & 337 & 13 & 15 & 1 \\
\hline $07 / 28 / 03$ & 183 & 400 & 10 & 16 & \\
\hline $07 / 31 / 03$ & 76 & 425 & 9 & 10 & \\
\hline 09/04/03 & 76 & 377 & 6 & 6 & 1 \\
\hline 09/13/03 & 183 & 427 & 18 & 22 & 2 \\
\hline 09/28/03 & 76 & 502 & 12 & 13 & \\
\hline $10 / 16 / 03$ & 76 & 400 & 4 & 5 & \\
\hline $12 / 04 / 03$ & 76 & 472 & 3 & 3 & \\
\hline $01 / 21 / 04$ & 76 & 503 & 11 & 12 & \\
\hline $01 / 21 / 04$ & 183 & 321 & 14 & 19 & \\
\hline $02 / 28 / 04$ & 76 & 494 & 18 & 18 & \\
\hline 03/06/04 & 183 & 478 & 15 & 15 & \\
\hline $03 / 25 / 04$ & 76 & 428 & 14 & 14 & \\
\hline $04 / 13 / 04$ & 183 & 247 & 5 & 5 & \\
\hline $04 / 20 / 04$ & 76 & 430 & 21 & 23 & \\
\hline $04 / 26 / 04$ & 76 & 504 & 33 & 39 & \\
\hline $05 / 29 / 04$ & 183 & 276 & 7 & 8 & \\
\hline $06 / 22 / 04$ & 76 & 360 & 12 & 14 & 1 \\
\hline $07 / 16 / 04$ & 76 & 504 & 8 & 11 & 3 \\
\hline Sum & & 10,701 & 346 & 406 & 17 \\
\hline
\end{tabular}

Km on effort = valid effort on both sides, $S$ number of sightings, $I$ number of individuals

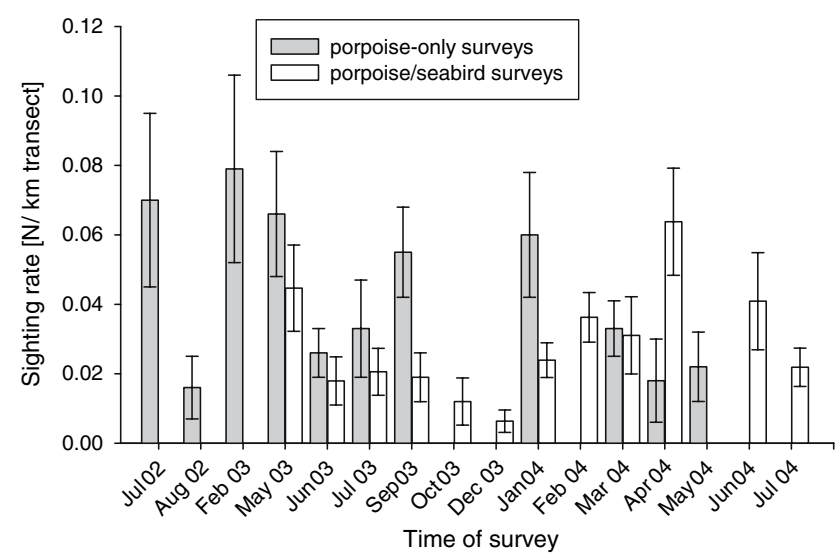

Fig. 3 Relative frequency of occurrence (n/transect $/ \mathrm{km}$ ) of harbour porpoises during the study period (mean $\pm \mathrm{SE}$ )

absolute density during the whole study period was 0.63 porpoises $/ \mathrm{km}^{2}(0.06 \pm \mathrm{SE} ; n=26)$ with the absolute densities being normally distributed $(\mathrm{K}-\mathrm{S}$-test, $P=0.35)$. 
Table 3 Densities of harbour porpoises in the study area in 2002-2004

$g(0)$ Probability of detection at distance $=0$ from the transect line, esw effective strip halfwidth, $C V$ coefficient of variation, $N$ estimated number of animals present in the study area, $\pm S E$ standard error

\begin{tabular}{|c|c|c|c|c|c|c|c|c|}
\hline Date & $\begin{array}{l}\text { Altitude } \\
(\mathrm{m})\end{array}$ & $g(0)$ & $\begin{array}{l}\text { esw } \\
(\mathrm{m})\end{array}$ & $\begin{array}{l}\text { Density } \\
(\text { Ind./.km²) }\end{array}$ & $\begin{array}{l}\text { Density } \\
\text { CV }\end{array}$ & $\begin{array}{l}\text { Area size } \\
\left(\mathrm{km}^{2}\right)\end{array}$ & $\mathrm{N}$ & $\pm \mathrm{SE}$ \\
\hline $07 / 28 / 02$ & 152 & 0.21 & 163 & 0.88 & 0.32 & 1,630 & 1,439 & 459 \\
\hline 08/16/02 & 152 & 0.21 & 163 & 0.23 & 0.47 & 1,630 & 388 & 183 \\
\hline $02 / 14 / 03$ & 183 & 0.21 & 163 & 1.23 & 0.34 & 1,630 & 2,020 & 688 \\
\hline $05 / 16 / 03$ & 76 & 0.21 & 112 & 1.06 & 0.29 & 2,670 & 2,858 & 822 \\
\hline $05 / 26 / 03$ & 183 & 0.21 & 163 & 0.98 & 0.24 & 1,630 & 1,600 & 391 \\
\hline $06 / 14 / 03$ & 183 & 0.21 & 163 & 0.26 & 0.49 & 1,630 & 427 & 209 \\
\hline 06/16/03 & 76 & 0.21 & 112 & 0.33 & 0.32 & 2,670 & 885 & 280 \\
\hline $06 / 22 / 03$ & 183 & 0.21 & 163 & 0.66 & 0.30 & 1,630 & 1,079 & 323 \\
\hline $07 / 28 / 03$ & 183 & 0.21 & 163 & 0.42 & 0.29 & 2,670 & 1,148 & 329 \\
\hline $07 / 31 / 03$ & 76 & 0.21 & 112 & 0.49 & 0.32 & 2,670 & 1,332 & 421 \\
\hline 09/04/03 & 76 & 0.21 & 112 & 0.37 & 0.46 & 2,670 & 1,003 & 465 \\
\hline $09 / 13 / 03$ & 183 & 0.21 & 163 & 0.72 & 0.21 & 2,670 & 1,936 & 412 \\
\hline $09 / 28 / 03$ & 76 & 0.21 & 112 & 0.56 & 0.46 & 2,670 & 1,504 & 697 \\
\hline $10 / 16 / 03$ & 76 & 0.21 & 112 & 0.23 & 0.53 & 2,670 & 629 & 335 \\
\hline $12 / 04 / 03$ & 76 & 0.21 & 112 & 0.14 & 0.51 & 2,670 & 400 & 204 \\
\hline $01 / 21 / 04$ & 76 & 0.21 & 112 & 0.51 & 0.22 & 2,670 & 1,376 & 298 \\
\hline $01 / 21 / 04$ & 183 & 0.21 & 163 & 0.74 & 0.28 & 2,670 & 2,002 & 571 \\
\hline $02 / 28 / 04$ & 76 & 0.21 & 112 & 0.85 & 0.20 & 2,670 & 2,292 & 460 \\
\hline 03/06/04 & 183 & 0.21 & 163 & 0.53 & 0.27 & 2,670 & 1,444 & 381 \\
\hline $03 / 25 / 04$ & 76 & 0.21 & 112 & 0.76 & 0.34 & 2,670 & 2,060 & 700 \\
\hline $04 / 13 / 04$ & 183 & 0.21 & 163 & 0.34 & 0.63 & 2,670 & 929 & 585 \\
\hline $04 / 20 / 04$ & 76 & 0.21 & 112 & 1.14 & 0.21 & 2,670 & 3,075 & 644 \\
\hline $04 / 26 / 04$ & 76 & 0.21 & 112 & 1.54 & 0.31 & 2,670 & 4,126 & 1,267 \\
\hline $05 / 29 / 04$ & 183 & 0.21 & 163 & 0.43 & 0.34 & 2,670 & 1,164 & 402 \\
\hline $06 / 22 / 04$ & 76 & 0.21 & 112 & 0.78 & 0.34 & 2,670 & 2,095 & 715 \\
\hline $07 / 16 / 04$ & 76 & 0.21 & 112 & 0.37 & 0.25 & 2,670 & 999 & 254 \\
\hline
\end{tabular}

In the second year of observations (July 2003-July 2004), porpoises were evenly distributed within the study area (Fig. 1). The distribution of sightings in the $10-\mathrm{km}$ zones around the centre was not significantly different across zones (porpoise-only: $H$-test, $H=1.587, d f=2$, $P=0.45$, porpoise/seabird surveys: $F$-test, $F=0.711$, $d f=3, P=0.557)$.

\section{Discussion}

Our study demonstrates a year-round but highly irregular appearance of harbour porpoises in the central German Bight during the period of 2002-2004. In contrast to other areas, the occurrence of porpoises was not correlated with seasons (e.g. Thomsen et al. 2006b; Scheidat et al. 2006; Siebert et al. 2006), but characterized by rather erratic peaks in density in certain months and in all seasons.

We should remember at this point that our calculation of $g(0)$ might be viewed as only a rough estimate and that other methods, for example the circle-back procedure (Hiby and Lovell 1998), might be more accurate, given that sample sizes are big enough. However, the value of 0.21 is in line with values from other investigations and we therefore assume it to be quite realistic (Hiby and Lowell 1998; Hammond et al. 2002; for a detailed discussion on this topic see Thomsen et al. 2005, 2006b). Another point that might be raised is that density estimates in comparably small survey areas, like the one used here, are particularly prone to small-scale and rather random shifts in distribution, especially for species moving around as much as harbour porpoises (Teilmann 2000). It is important in such cases to avoid misinterpretation of presumably distributional shifts as temporal changes (Buckland et al. 2001). We are aware of this uncertainty in interpreting our results; however, this critique might also apply for large-scale surveys with comparably low coverage within survey blocks, as in this case, clusters of animals within strata might be missed. We are therefore confident that we picked a rather efficient tradeoff between area size and coverage. Our results on the seasonality of harbour porpoises off Eastern Frisia, obtained in an area of comparable size as the one used here (see 
Thomsen et al. 2006b), agree well with the ones from other studies in that region (Camphuysen 2004; Haelters et al. 2004).

We found the overall absolute density to be 0.63 porpoises per $\mathrm{km}^{2}$, a value that is very similar to the ones obtained by larger-scale surveys covering our study area and adjacent waters (Scheidat et al. 2004b). Harbour porpoise densities in our study area might have remained at a relatively constant level since 1994, as the results of the SCANS I and II surveys in blocks comprising the central German Bight are similar (Hammond et al. 2002; Hammond 2006). The findings that the differences across sighting rate values for the porpoise-only flights were nonsignificant should not be too easily interpreted as being due to random-sampling variability. The number of transects is crucial in line-transect sampling and the value we had to choose to guarantee a safe return after survey with still ample coverage of the region (8/10) is at the lower limit of what is needed to produce quantitative results (Buckland et al. 2001). We therefore assume that the peaks we obtained in single months are based on true biological phenomena that would prove to be statistically significant with the addition of more transects (see Thomsen et al. 2006b). The results of the porpoise/seabird surveys, with the sighting rate in April 2004 being significantly higher than during other months, support this conclusion.

The differences between surveys might be explained by two not mutually exclusive mechanisms. From previous studies, it is apparent that the central German Bight is located between two regions with high densities of harbour porpoises during different times of the year. One is located off Northern Frisia with high densities between May and August (Hammond et al. 2002; Scheidat et al. 2004a, b; Siebert et al. 2006). The other is located off Eastern Frisia, with high occurrence of porpoises from February to the beginning of May (Camphuysen 2004; Haelters et al. 2004; Piper et al. 2004; Thomsen et al. 2006b). It is possible that porpoises from these high-density areas move into and out of the central German Bight on a rather sporadic basis. That would explain the relatively high densities we found in February, April, May and July. It would also explain the comparably high number of calves we found in certain surveys, as Northern Frisia and adjacent waters might function as a calving ground for porpoises in the North Sea (Sonntag et al. 1999; Hammond et al. 2002; Siebert et al. 2006). Another or an additional way to interpret the results would be that porpoises transit the central German Bight during migratory movements from Northern Frisia into offshore areas in fall and winter. That would explain the higher densities we found in September and January. The high densities we found in April and May would be explained by another migratory movement that might take place during late spring, when porpoises move out of Eastern Frisia.
These hypotheses could only be tested using marked animals or with satellite telemetry.

Acknowledgments We would first like to thank the "Nordsee Windpower" GmbH \& Co. KG for the opportunity to present the data. We thank the other observers Mareike Buck, Thilo Christophersen, Lorna Deppe, Lutz von der Heyde, Manuela von der Heyde, Gudrun Hofmann, Karsten Kohls, Jochen Lempert, Annika Meyer-Burbach, Regina Paul, Hans-Jürgen Pelny, Martin Plath, Annette Wegener, Scott Wischhof and Torsten Wronski for their great engagement for the project. Danja Kölln was invaluable in her tireless effort with the database. We would like to thank the "Ostfriesische Lufttransport GmbH" (OLT, Emden) and Mr. Beekhuis, Breier, Fieseler, Marzanek, Soons and Urban for the close cooperation in managing and executing the survey flights. We are grateful to Meike Scheidat and Robin Law for comments on an earlier version of the paper.

\section{References}

Borchers DL (2003) Estimation with incomplete detection at distance zero " $\mathrm{g}(0)<1$ ". In: International workshops. Advanced techniques and recent developments in distance sampling. Centre for Research into Ecological and Environmental Modelling, St Andrews, pp 102-129

Buckland ST, Anderson DR, Burnham KP, Laake JL, Borchers DL, Thomas L (2001) Introduction to distance sampling. Oxford University Press, Oxford

Camphuysen CJ (1994) The harbour porpoise Phocoena phocoena in the southern North Sea: a come-back in Dutch coastal waters? Lutra 37:54-61

Camphuysen CJ (2004) The return of the harbour porpoise (Phocoena phocoena) in Dutch coastal waters. Lutra 47:113-122

Grünkorn TA, Diederichs A, Nehls G (2005) Aerial surveys in the German Bight--estimating $\mathrm{g}(0)$ for harbour porpoises (Phocoena phocoena) by employing independent double counts. In: Thomsen F, Ugarte F, Evans PGH (eds) Estimation of $g(0)$ in line-transect surveys of cetaceans. European Cetacean Society Newsletter No. 44-special issue, pp 25-34

Haelters J, Kiska, JJ, Jauniaux, T, Tavernier, J (2004) The harbour porpoise in the southern North Sea a come-back in northern French and Belgian waters? In: Abstracts of the $18^{\text {th }}$ annual conference of the European Cetacean Society (ECS), p 67, Kolmarden, 28-31 March 2004

Hammond (2006) Small cetaceans in the European Atlantic and North Sea: estimates of abundance. Presentation at the SCANS II conference 2006 (http://biology.st-andrews.ac.uk/scans2/conference.htm)

Hammond PS, Berggren P, Benke H, Borchers DL, Collet A, HeideJørgensen MP, Heimlich S, Hiby AR, Leopold MF, Øien N (2002) Abundance of the harbour porpoise and other cetaceans in the North Sea and adjacent waters. J Appl Ecol 41:1129-1139

Hiby AR, Lovell P (1998) Using aircraft in tandem formation to estimate abundance of harbour porpoises. Biometrics 54:1280-1289

Madsen PT, Wahlberg M, Tougaard J, Lucke K, Tyack P. (2006) Wind turbine underwater noise and marine mammals: implications of current knowledge and data needs. Mar Ecol Prog Ser 309:279-295

Perrin WF, Wuersig B, Thewissen JGM (2002) Encyclopedia of marine mammals. Academic Press, San Diego

Piper W, Brock V, Laczny M, Thomsen F (2004) A study on the winter distribution and abundance of harbour porpoises (Phocoena phocoena) in the German Bight using aerial and shipboard surveys. In: Abstracts of the $18^{\text {th }}$ Annual Conference of the European Cetacean Society (ECS), p 74, Kolmarden, 28-31 March 2004 
Scheidat M, Gilles A, Siebert U (2004a) Erfassung der Dichte und Verteilungsmuster von Schweinswalen (Phocoena phocoena) in der deutschen Nord- und Ostsee-Teilprojekt 3. In: Endbericht Marine Warmblüter in Nord- und Ostsee-Grundlagen zur Bewertung von Windkraftanlagen im Offshore-Bereich. Bundesministerium für Umwelt, Naturschutz und Reaktorsicherheit (FKZ 0327520)

Scheidat M, Kock KH, Siebert U (2004b) Summer distribution of harbour porpoise (Phocoena phocoena) in the German North Sea and Baltic Sea. J Cetacean Res Manag 6:251-257

Scheidat M, Siebert U, Gilles A, Lehnert K, Risch D, Kaschner K, Westerberg U (2006) TP2-Erfassung der Dichte und Verteilungsmuster von Schweinswalen (Phocoena phocoena) in der deutschen Nord- und Ostsee. In: Minos/Plus-Weiterführende Arbeiten an Seevögeln und marinen Säugern zur Bewertung von OffshoreWindkraftanlagen. Zweiter Zwischenbereicht, April 2006. Landesamt für den Nationalpark Schleswig-Holsteinisches Wattenmeer, Tönning, pp 10-27

Siebert U, Gilles A, Lucke K, Ludwig M, Benke H, Kock KH, Scheidat M (2006) A decade of harbour porpoise occurrence in German waters: analysis of aerial surveys, incidental sightings and strandings. J Sea Res 56:65-80

Sonntag RP, Benke H, Hiby AR, Lick R, Adelung D (1999) Identification of the first harbour porpoise (Phocoena phocoena) calving ground in the North Sea. J Sea Res 41:225-232

Teilmann J (2000) The behaviour and sensory abilities of harbour porpoises (Phocoena phocoena) in relation to bycatch in Danish gillnet fishery. Ph.D. thesis, University of southern Denmark, Odense

Thomas L, Laake JL, Strindberg S, Marques FFC, Buckland ST, Borchers DL, Anderson DR, Burnham KP, Hedley SL, Pollard JH (2003) Distance 4.1 Release 2. Research Unit for Wildlife Population Assessment, University of St Andrews, UK http:// www.ruwpa.st-and.ac.uk/distance/

Thomsen F, Laczny M, Piper W (2004) Methodik zur Erfassung von Schweinswalen (Phocoena phocoena) und anderen marinen Säugern mittels Flugtransekt-Zählungen. Seevögel 25:3-12

Thomsen F, Ugarte F, Evans PGH (2005) Estimation of g(0) in linetransect surveys of cetaceans. European Cetacean Society Newsletter No. 44-SPECIAL ISSUE, ECS (available at: http:// www.web.inter.nl.net/users/J.W.Broekema/ecs/)

Thomsen F, Lüdemann K, Kafemann R, Piper W (2006a) Effects of offshore wind farm noise on marine mammals and fish. Report for Collaborative Offshore Wind Research into the Environment (COWRIE), Newbury

Thomsen F., Laczny M., Piper W. (2006b) A recovery of harbour porpoises (Phocoena phocoena) in the southern North Sea? A case study off Eastern Frisia, Germany. Helgol Mar Res 60:189-195

Witte RH, Baptist HJM, Bot PVM (1998) Increase of harbour porpoise (Phocoena phocoena) in the Dutch sector of the North Sea. Lutra 40:33-40

Zar JH (1984) Biostatistical analysis, 2 edn. Prentice Hall, Englewood Cliffs 